INVITED REVIEW

\title{
Genetic variation in thyroid hormone pathway genes; polymorphisms in the TSH receptor and the iodothyronine deiodinases
}

\author{
Robin P Peeters, Wendy M van der Deure and Theo J Visser \\ Department of Internal Medicine, Erasmus University Medical Center, Dr Molewaterplein 40, 3015 GD, Rotterdam, The Netherlands \\ (Correspondence should be addressed to R P Peeters; Email: r.peeters@erasmusmc.nl)
}

\begin{abstract}
Serum thyroid parameters show substantial inter-individual variability, in which genetic variation is a major factor. Findings in patients with subclinical hyper- and hypothyroidism illustrate that even minor alterations in serum thyroid function tests can have important consequences for a variety of thyroid hormone-related clinical endpoints, such as atherosclerosis, bone mineral density, obesity, and heart rate. In the last few years, several studies described polymorphisms in thyroid hormone pathway genes that alter serum thyroid function tests. In this review, we discuss the genetic variation in the TSH receptor and iodothyronine deiodinases. We discuss the possible consequences of these studies for the individual patient and also the new insights in thyroid hormone action that can be obtained from these data.
\end{abstract}

European Journal of Endocrinology 155 655-662

\section{Introduction}

Thyroid hormone is essential for growth and differentiation, for the regulation of energy metabolism, and for the physiological function of virtually all human tissues. The production of thyroid hormone is regulated by the classic hypothalamus-pituitary-thyroid axis, whereas the biological activity of thyroid hormone (i.e. the availability of the active hormone triiodothyronine (T3) for the nuclear thyroid hormone receptors) is mainly regulated at the tissue level by the iodothyronine deiodinases and thyroid hormone transporters.

In healthy subjects, serum thyroid parameters show substantial inter-individual variability, whereas the intraindividual variability is within a narrow range (1). This suggests an important influence of genetic variation, in addition to environmental factors such as food or iodine intake, on the regulation of thyroid hormone bioactivity, resulting in a thyroid function set-point that is different for each individual. This notion is supported by a classical twin study that was recently published (2). In this study, heritability accounted for $\sim 65 \%$ of the variation in serum thyroid stimulating hormone (TSH), free thyroxine (FT4), and free T3 (FT3) levels. In a Mexican-American population, total heritability in serum thyroid parameters ranged from 26 to $64 \%$ of the total inter-individual variation observed (3).

Findings in patients with subclinical hyper- and hypothyroidism illustrate that even minor alterations in thyroid hormone levels (and in thyroid hormone bioactivity) can have important consequences for a variety of thyroid hormone-related clinical endpoints, such as atherosclerosis, bone mineral density, obesity, and heart rate (4-6). In the last few years, several studies described polymorphisms in thyroid hormone pathway genes that result in an altered thyroid hormone bioactivity. Some of these polymorphisms are associated with serum TSH and/ or thyroid hormone levels in healthy subjects, and/ or with thyroid hormone-related clinical endpoints. As DNA variations are stable throughout life, such genetic effects are likely to have an influence during the lifetime of subjects.

In this review, we discuss the genetic variation in thyroid hormone pathway genes, focusing on the polymorphism studies that have emerged in the last few years. For the sake of brevity, we have focused on single nucleotide polymorphisms (SNPs) in the TSH receptor and iodothyonine deiodinases, since only these genes are presently analyzed for possible associations with serum thyroid hormone levels. Besides their relation with serum thyroid hormone levels, we discuss the effects of these polymorphisms on clinical endpoints such as Graves' disease and insulin resistance. Furthermore, we discuss the possible consequences of these studies for the individual patient, and also the new insights in thyroid hormone action that can be obtained from these data. 


\section{Polymorphisms in the TSH receptor}

Many somatic gain-of-function mutations in the TSH receptor (TSHR) have been described, which result in a phenotype of toxic adenoma or toxic multinodular goiter (7). Germline gain-of-function TSHR mutations that result in congenital hyperthyroidism have also been described. Conversely, germline loss-of-function TSHR mutations are associated with TSH resistance and congenital hypothyroidism (see reference (8) for an illustrative example). However, only three germline TSHR polymorphisms, resulting in amino acid substitutions, have been identified (9-11). Two of these are located in the extracellular domain of the receptor (Asp36His and Pro52Thr) $(9,10)$, and one is located in the intracellular domain (Asp727Glu) (11) (Fig. 1). In addition, several intronic microsatellite markers and intronic SNPs have been described in TSHR (12-16).

The TSHR-Glu727 allele was associated with lower levels of plasma TSH in a population of healthy blood donors, but had no effect on FT4 (17). Recently, we have confirmed this observation in unrelated study populations $(18,19)$. This could point toward a higher sensitivity of the variant versus the wild-type TSHR, since less TSH is needed to produce normal FT4 levels. Although there is one in vitro study showing that the TSHR-Glu 727 variant results in an increased cAMP response of the receptor to TSH (11), others have not been able to replicate this (20, 21). A different explanation would be that the Asp $727 \mathrm{Glu}$ polymorphism is linked to another polymorphism elsewhere in the gene. The TSHR-Asp727Glu polymorphism is found to be within a linkage disequilibrium block starting at intron 8 and extending about $10 \mathrm{~kb}$ beyond the $3^{\prime}$ UTR of the TSHR gene (22).

Conflicting data are also available regarding the response of the TSHR-Pro52Thr variant to TSH stimulation (23-25). This might reflect the subtle effects of these polymorphisms. The TSHR-Pro52Thr and -Asp36His polymorphisms were not associated with changes in serum TSH or iodothyronine levels in healthy blood donors. However, this could be attributable to the low allele frequency of these SNPs (6 and $0.6 \%$ respectively) resulting in a lack of power.

No data on polymorphisms resulting in a relative loss of function of the TSHR are yet available. Subjects with a heterozygous loss of function mutation appear to have a dominant transmission of partial TSH resistance, which is due to intracellular entrapment and reduced maturation of the wild-type TSHR by the inactive mutants (26). Similarly, polymorphisms resulting in a relative loss of function could have an impact via this mechanism, and possibly account for some of the so-called 'euthyroid outliers' with elevated TSH determinations.

Besides effects on serum thyroid hormone levels, polymorphisms in the TSHR may also have effects on the development of autoimmune thyroid disease. The TSHR gene is located on chromosome 14q31, an area in which a Graves' disease susceptibility locus (GD-1) has been mapped (27). The GD-1 locus is
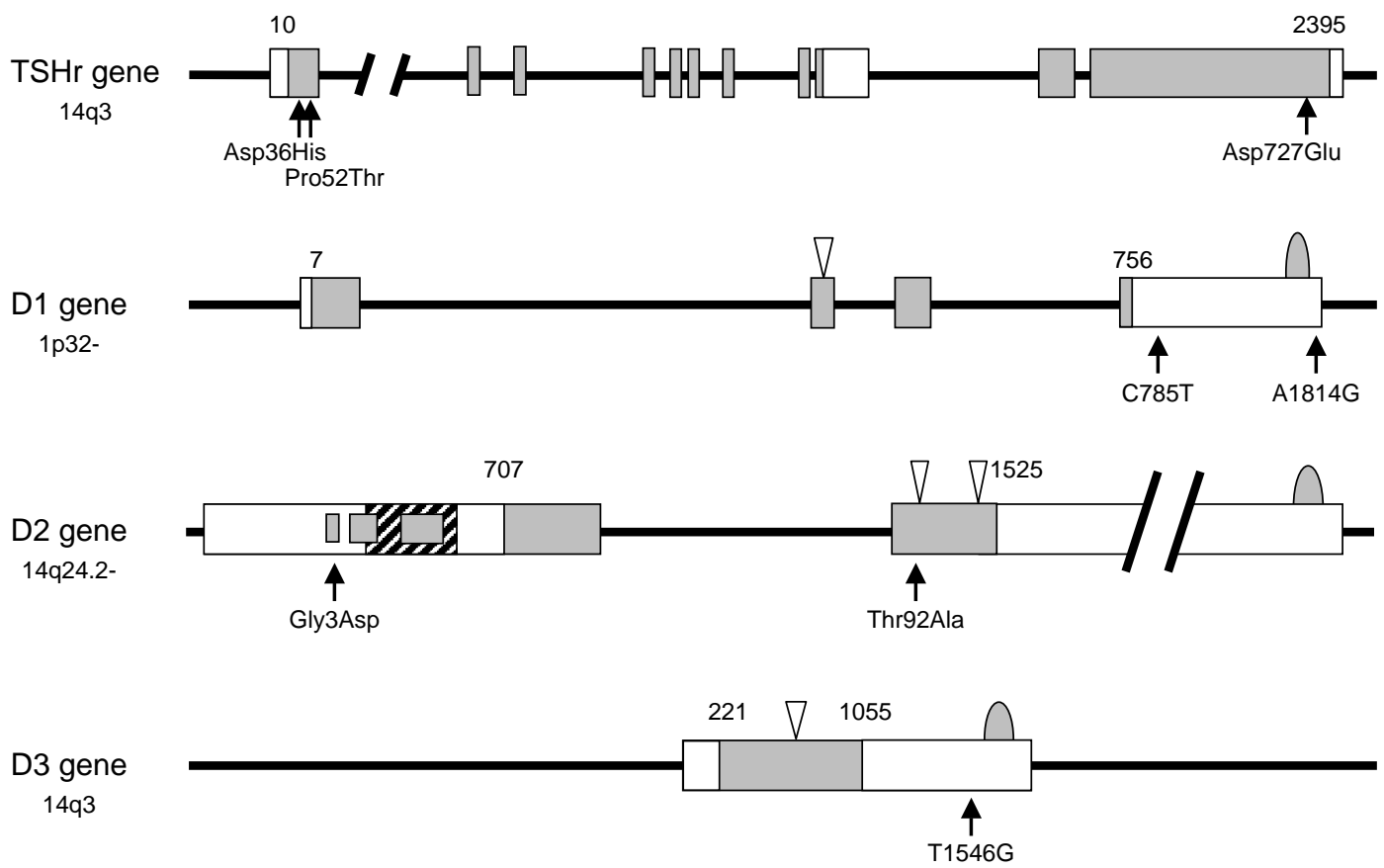

Figure 1 Exonic polymorphisms in the thyroid stimulating hormone receptor (TSHr) and the deiodinases that are described in this study (D1-3). The coding sequence is represented by $\square$, the $5^{\prime}$ and $3^{\prime} U T R$ by $\square$, whereas $\square$ represents an alternatively spliced exon. A UGA codon, coding for selenocysteyl, is depicted by $\nabla$. Finally, selenocysteine insertion sequence elements are indicated by $\cap$. 
specifically linked to Graves' disease, but not Hashimoto's thyroiditis or autoimmune thyroid disease in general. Several case-control studies have been carried out analyzing the possible association between one or more of the previously mentioned TSHR polymorphisms and autoimmune thyroid disease. An overview of the 14 studies up to 2002 that analyzed the possible association of TSHR polymorphisms with Graves' disease has been presented by Ban et al. (28).

All studies analyzing the TSHR-Pro52Thr or Asp36His variant showed no association, apart from one in which an association of the TSHR-Pro52Thr variant with Graves' disease was described in US Caucasian females $(n=100$ females with autoimmune thyroid disease versus 69 controls) (29). These same authors later described two subjects who were homozygous for the Thr52 allele and had normal thyroid function tests, on the basis of which they suggested that the variant receptor is able to respond normally to TSH (23). Obviously, more subtle effects of this polymorphism cannot be excluded by the last study. In a multiethnic (Chinese, Malays, and Indians) cohort of patients with Graves' disease, TSHR-Asp36His was absent, and TSHR-Pro52Thr and -Asp727Glu were not associated with Graves' disease (30). Unfortunately, no data are presently available if the two variants in the extracellular domain of the receptor show altered binding of thyroid-stimulating antibodies. Nor are any data available regarding altered binding or altered cAMP response of the variant $\mathrm{TSH}$ receptor to a different TSHR ligand termed thyrostimulin that has recently been identified (31).

Three case-control studies in Caucasians showed no association between the TSHR-Asp727Glu polymorphism and Graves' disease (11, 28, 32). However, meta-analysis of these three studies (28), as well as a study in Russian patients ( $n=78$ vs 93 controls), showed a weak association of the variant receptor with Graves' disease (33, 34). These Graves' patients showed a significantly higher frequency of the TSHRGlu727 allele than did healthy subjects $(33,34)$. A recent transmission disequilibrium test (TDT) study in Russian families showed that the D2-Thr92Ala (see below) and TSHR-Asp727Glu polymorphisms are in weak linkage disequilibrium (35), and that the D2Ala92/TSHR-Glu727 haplotype allele was preferentially transmitted from parents to affected siblings with Graves' disease (35). However, TDT is not the best design to analyze linkage disequilibrium.

A recent study in Japanese patients with autoimmune thyroid disease showed that several SNPs in intron 7 of the TSHR gene are significantly associated with Graves' disease (14). Another polymorphism in intron 4 of TSHR was associated with Graves' disease in a multiethnic population of patients from Singapore (30). Recently, a study in which common haplotype tagging SNPs in TSHR were analyzed showed a significant association of intronic SNPs in one linkage disequilibrium block with Graves' disease (22).

These data together suggest that genetic variation in TSHR is, albeit weakly, associated with the development of Graves' disease, but it is yet unclear whether the associated polymorphisms are functional or whether they are linked to functional variants elsewhere in the gene or in the nearby genome that are still to be discovered. Meta-analysis, detailed linkage disequilibrium analysis, and haplotype tagging approaches (as well as the HapMap project, www.hapmap.org) should be able to resolve this issue (36).

TSHR is not only expressed in the thyroid, but also in adipose tissue $(37)$, brain $(38)$, orbital tissue $(37,39)$, lymphocytes (40), and bone (41). Evidence is accumulating for direct effects of TSH via the TSHR on these tissues. TSH is able to induce proliferation and inhibit differentiation in cultured rat pre-adipocytes (42), and TSHR knockout mice have a severe phenotype of osteoporosis, independent of their thyroid hormone levels (41). Genetic variation in TSHR may thus not only be important for the development of autoimmune thyroid disease (more specifically Graves' disease), but may also be associated with more common clinical endpoints such as osteoporosis (19), either via its influence on thyroid hormone levels, or via direct effects of TSH on bone.

\section{Polymorphisms in the iodothyronine deiodinases}

No patients with inactivating mutations in any of the iodothyronine deiodinases have yet been described. Whether this means that these mutations are not compatible with life, that they have little or no consequences, or that they result in unexpected phenotypes is unclear. Based on the phenotypes of mice with targeted deletions of D1, D2, or D3, the most severe effects would be expected of mutations in D3 (43-45). In the last few years, several polymorphisms in deiodinases have been described $(17,46,47)$ (Fig. 1). Based on the physiological role of the three different deiodinases (48) (Table 1), one can speculate about the possible consequences of polymorphisms in these enzymes. D1 is present in liver, kidney, and thyroid, and plays a key role in the production of the active hormone $\mathrm{T} 3$ from $\mathrm{T} 4$ and in the clearance of the metabolite reverse T3 (rT3) $(48,49)$. D2 is present in brain, pituitary, brown adipose tissue, thyroid, skeletal muscle, aortic smooth muscle cells, and osteoblasts; D2 mRNA has also been detected in the human heart (48). In tissues such as the brain, D2 is important for local production of T3, whereas D2 in skeletal muscle may also contribute to plasma T3 production. D3 is present in brain, skin, placenta, pregnant uterus, and various fetal tissues, and is induced in critical illness $(48,50)$. D3 is the major T3 and T4 inactivating enzyme and 
Table 1 Physiological role in thyroid hormone metabolism, tissue distribution, and substrate preference of the three human iodothyronine selenodeiodinases (D1-D3).

\begin{tabular}{|c|c|c|c|}
\hline & 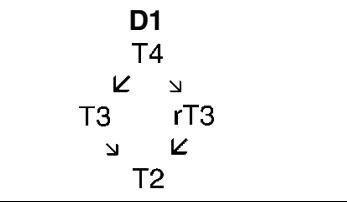 & 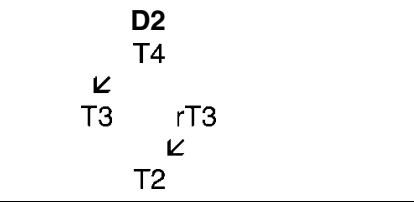 & $\begin{array}{c}\text { D3 } \\
\text { T3 }{ }_{\substack{\mathrm{y} \\
\mathrm{y}}}^{\mathrm{rT} 3}{ }_{\mathrm{T} 2}\end{array}$ \\
\hline Function & $\begin{array}{l}\text { Plasma T3 production, rT3 } \\
\text { clearance }\end{array}$ & Local and plasma T3 production & T3 and T4 clearance, rT3 production \\
\hline $\begin{array}{l}\text { Tissue } \\
\text { distribution }\end{array}$ & Liver, kidney, thyroid & $\begin{array}{l}\text { Brain, pituitary, BAT, thyroid, } \\
\text { skeletal muscle, heart, aortic } \\
\text { smooth muscle, osteoblasts }\end{array}$ & $\begin{array}{l}\text { Brain, skin, placenta, fetal tissues, critically } \\
\text { ill liver and skeletal muscle }\end{array}$ \\
\hline $\begin{array}{l}\text { Substrate } \\
\text { preference }\end{array}$ & $\mathrm{rT} 3 \gg \mathrm{T} 4=\mathrm{T} 3$ & $\mathrm{~T} 4>\mathrm{rT3}$ & $\mathrm{T} 3>\mathrm{T} 4$ \\
\hline
\end{tabular}

T3, triiodothyronine; T4, thyroxine; rT3, reverse triiodothyronine; BAT, brown adipose tissue.

contributes to thyroid hormone homeostasis by protecting tissues from excess thyroid hormone. The T3/rT3 ratio is considered to be a sensitive indicator of the peripheral metabolism of thyroid hormone, being positively influenced by D1 and D2 and negatively by D3. This ratio is also relatively independent of thyroidal T4 production and of variations in serum binding proteins. In addition to genetic variation, the peripheral metabolism of thyroid hormone can be influenced by factors such as iodine deficiency, nutritional status, and disease.

\section{D1}

Recently, two polymorphisms in D1 (D1-C785T and D1A1814G) that affect the serum T3/rT3 ratio in healthy subjects have been identified (17) (Fig. 1). The D1-785T allele is associated with higher levels of rT3 and with a lower T3/rT3 ratio. Based on the function of D1 (Table 1 ), it was speculated that the D1-785T variant results in a decreased activity of D1. The D1-1814G allele was associated with a higher $\mathrm{T} 3 / \mathrm{rT} 3$ ratio, suggesting that the D1-1814G variant may result in increased activity (17). Since both polymorphisms are located in the $3^{\prime}$-UTR of the mRNA, a change in the stability of the mRNA is an attractive explanation for their effect. Alternative explanations include an altered folding of the mRNA, in particular of the selenocysteine insertion sequence (SECIS), which is necessary for the incorporation of a selenocysteine residue in the catalytic center of the protein (48), or linkage with other polymorphisms in the coding sequence or in regulatory regions of the gene. Functional testing and haplotype analysis will be necessary to resolve this issue. Although the D1-785T variant is not associated with serum rT3 levels in a population of 350 elderly men (age $>70$ years), its association with lower levels of T3 in this elderly population supports the hypothesis of a lower activity of D1 in carriers of this polymorphism (51). The difference in associations found in the healthy blood donors and the elderly men might be explained by the difference in age, with means of 46 vs 77 years respectively. In young subjects, a decreased T3 production by D1 may be masked by the production of serum T3 by skeletal muscle D2. Throughout adult life, skeletal muscle size and strength gradually decline, resulting in a decrease in D2-expressing skeletal muscle. Furthermore, rT3 levels increase with age, and degradation of the D2 protein is accelerated when it is exposed to its own substrates T4 and rT3 (52). Although it has been shown that D1 activity also decreases during aging (53), the relative contribution of $\mathrm{D} 2$ to serum $\mathrm{T} 3$ production may be less important in the elderly than in young subjects. This would mean that D1 has a relatively greater contribution to serum T3 production at advanced ages (51) (Fig. 2). In line with this hypothesis is the recent publication of a polymorphism in a short open reading frame (ORFa) in the $5^{\prime}$-UTR of D2, which has been shown to be an important regulatory element $(47,54)$ (Fig. 2). This polymorphism (D2-ORFa-Gly3 Asp) is associated with the serum T3/T4 ratio in young, but not elderly, subjects (47). Also supporting this hypothesis is the association of the D1C785T polymorphism with both serum T3 and rT3 levels in an unrelated third population, with an average

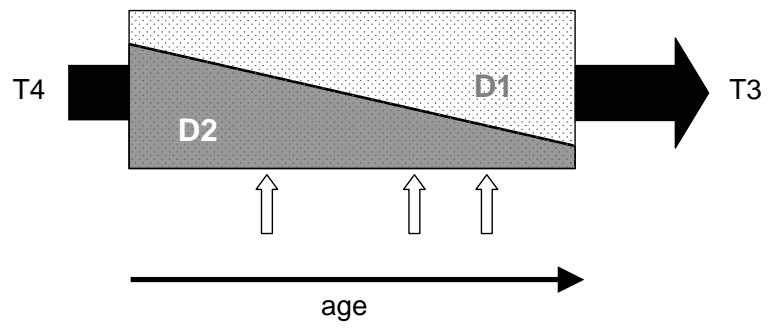

Figure 2 Illustration of the proposed model in which the relative contribution of $\mathrm{D} 2$ to serum triiodothyronine (T3) production decreases with an increase in age, based on the different associations of D1 and D2 polymorphisms with serum iodothyronines in one younger (left arrow, 46 years) and two elderly populations (right two arrows, 69 and 77 years respectively). $\mathrm{T4}$, thyroxine. 
age of 69 years (RP Peeters, WM van der Deure, T] Visser, unpublished observations).

Haplotype analysis showed that the D1-C785T and D1-A1814G polymorphisms appear on different haplotype alleles $(17,51)$. The haplotype allele containing D1-785T is not only associated with changes in serum iodothyronine levels, but also with increased levels of free insulin-like growth factor-I (IGF-I) in two unrelated populations (51). This was substantiated by the association of this haplotype allele with several IGF-Irelated endpoints, such as increased muscle strength and muscle mass (51). As IGF-I has a stimulatory effect on D1 expression (55), these higher levels of free IGF-I might be seen as an adaptation to normalize D1 activity in carriers of the D1a-T haplotype allele. Conversely, thyroid hormone stimulates the expression of IGFbinding protein-I (IGFBP-I) in human hepatoma cells (56). A lower activation of thyroid hormone by liver D1 could result in lower levels of IGFBP-1, and thus a higher level of free IGF-I (51), as the majority of IGFBP-1 is produced in the liver.

\section{D2}

D2 is important in the production of local T3, but D2 in skeletal muscle also contributes to serum T3 production $(48,57)$. The above-mentioned association of D2-ORFa-Gly3Asp with the serum T3/T4 ratio also points toward an important role of $\mathrm{D} 2$ in serum $\mathrm{T} 3$ production $(47,51)$.

The first polymorphism described in any of the deiodinases was D2-Thr92Ala (46) (Fig. 1). Although this polymorphism does not seem to be associated with serum iodothyronine levels, it has been associated with insulin resistance in three different populations $(46,58$, 59). The mechanism behind this association is yet unclear, but it might involve expression of D2 in skeletal muscle and/or in (brown) fat in humans (48). T3 stimulates the transcription of the muscle/fat-specific insulin-sensitive glucose transporter GLUT4 (60). In addition, thyroid hormone augments catecholaminestimulated lipolysis (61), and a particular inactivating thyroid hormone receptor $\alpha$ mutation results in insulin resistance in mice (62). A decreased D2 activity in insulin-sensitive tissues such as adipose tissue and skeletal muscle, resulting in a decreased availability of local T3, may thus explain the association of D2-Thr92Ala with relative insulin resistance $(46,58$, 59). Furthermore, it was recently shown that administration of bile acids to mice can increase energy expenditure, and thereby prevent obesity and insulin resistance via the induction of D2 (63). Alternatively, hypothalamic D2, which regulates the T3 content of brain stem neurons projecting to white adipose tissue, may be involved (64). Although D2 activity does not differ between different cells that are transfected with the D2-92Thr or the D2-92Ala variant $(17,58)$, a lower activity of D2 has been reported in muscle and thyroid homogenates of carriers of the D2-Ala92 allele (58). This suggests that the consequences of the D2Thr92Ala polymorphism are caused by linkage with another polymorphism. Haplotype analysis has shown that the D2-Thr92Ala polymorphism and the previously mentioned D2-ORFa-Gly3Asp polymorphism appear on different haplotype alleles (47). So far, there is no evidence of any relationship between the D2ORFa-Gly3Asp polymorphism and insulin resistance.

Based on the expression pattern of D2, and since D2 is crucial in the regulation of local $\mathrm{T} 3$ concentrations, one can speculate about other possible consequences of these and other D2 polymorphisms. Guo et al. studied the relation of the DIO2 gene with mental retardation in iodine-deficient areas of China in a case-control study ( $n=96$ vs 331 controls) (65). They found a positive association of two intronic D2 polymorphisms (but not of D2-Thr92Ala) with mental retardation in these areas (65), and concluded that genetic variation in D2 may determine the risk of developing mental retardation in an iodine-deficient area, probably by affecting the local amount of T3 available in the brain (65). Appelhof et al. addressed the questions whether genetic variation in the DIO2 gene is a determinant of well-being and neurocognitive functioning in hypothyroid patients on levothyroxine substitution, and whether D2 polymorphisms were associated with a preference for T4/T3 combination therapy over substitution with $\mathrm{T} 4$ alone (66). No differences in well-being, neurocognitive functioning or appreciation of $\mathrm{T} 4 / \mathrm{T} 3$ combination therapy were detected in these thyroid hormonereplaced hypothyroid patients (66).

\section{D3}

Until now, only one polymorphism has been identified in D3 (D3-T1546G), located in the 3'-UTR (17). This polymorphism does not result in altered thyroid hormone levels in healthy individuals. D3 plays an important role in thyroid hormone homeostasis in critical illness and during fetal development, providing protection against thyroid hormone excess $(50,67)$. Possible effects of this polymorphism on development and under pathophysiological conditions therefore remain to be investigated in future studies. A major obstacle in these studies is that the D3 gene is an imprinted gene, with preferential expression from the paternal allele, as has been studied in a mouse model (43). Therefore, the effects of polymorphisms in the DIO3 gene on thyroid hormone homeostasis depend on the parental origin of the variant allele.

\section{Concluding remarks and future perspectives}

Here, we have discussed several polymorphisms in TSHR and the iodothyronine deiodinases that affect 
serum thyroid hormone levels and/or have effects on thyroid hormone-related physiological endpoints. These polymorphism studies are important for several reasons. First, new insight can be obtained about the physiological function of thyroid hormone pathway genes. The hypothesis regarding a relative decrease in the contribution of D2 to serum T3 production (Fig. 2), based on the different associations of D1 and D2 polymorphisms in younger and elder populations, is an example of this $(17,51)$, as is the role of D2 activity in the development of insulin resistance $(46,47,58)$. Second, genetic variation is important in inter-individual variation in thyroid hormone bioactivity (1-3). It seems that each individual has a different, genetically determined thyroid function set-point, and that small variations around this set-point, even within the normal range, can have important consequences on, for example, body weight (6). A better selection of subjects, by excluding subjects with autonomous thyroid nodules $(68,69)$, and standardized (regarding time of day) and perhaps multiple TSH measurements to better define an individual's set-point (1), would increase the power of such association studies. This raises the possibility of estimating an individual's set-point based on his/her genetic make-up of thyroid hormone pathway genes. The decision of whether a patient with subclinical changes in thyroid parameters should be treated might then be made on that individual patient's normal values. In addition, the decision to treat patients with subclinical thyroid disease is based on the risk of these patients developing complications. If the genetic profile makes a patient more vulnerable, then this might be an indication to initiate treatment in an earlier phase.

In addition to peripheral metabolism of thyroid hormone by the deiodinases, transmembrane transport of iodothyronines and expression of thyroid hormone receptors are other key processes in the regulation of thyroid hormone bioactivity. Surprisingly, no studies have yet been published investigating the association of polymorphisms in these transporters and receptors with clinical endpoints. This area of research remains to be explored, and it is likely that exciting new insights will be obtained in the upcoming years.

\section{Acknowledgements}

This work was supported by ZonMw Grant: 920-03146 (RPP).

\section{References}

1 Andersen S, Pedersen KM, Bruun NH \& Laurberg P. Narrow individual variations in serum $\mathrm{T}(4)$ and $\mathrm{T}(3)$ in normal subjects: a clue to the understanding of subclinical thyroid disease. Journal of Clinical Endocrinology and Metabolism 200287 1068-1072.
2 Hansen PS, Brix TH, Sorensen TI, Kyvik KO \& Hegedus L. Major genetic influence on the regulation of the pituitary-thyroid axis: a study of healthy Danish twins. Journal of Clinical Endocrinology and Metabolism 200489 1181-1187.

3 Samollow PB, Perez G, Kammerer CM, Finegold D, Zwartjes PW, Havill LM, Comuzzie AG, Mahaney MC, Goring HH, Blangero J, Foley TP \& Barmada MM. Genetic and environmental influences on thyroid hormone variation in Mexican Americans. Journal of Clinical Endocrinology and Metabolism 200489 3276-3284.

4 Toft AD. Clinical practice. Subclinical hyperthyroidism. New England Journal of Medicine 2001345 512-516.

5 Cooper DS. Clinical practice. Subclinical hypothyroidism. New England Journal of Medicine 2001345 260-265.

6 Knudsen N, Laurberg P, Rasmussen LB, Bulow I, Perrild H, Ovesen L \& Jorgensen T. Small differences in thyroid function may be important for body mass index and the occurrence of obesity in the population. Journal of Clinical Endocrinology and Metabolism 200590 4019-4024.

7 Krohn K \& Paschke R. Somatic mutations in thyroid nodular disease. Molecular Genetics and Metabolism 200275 202-208.

8 Sunthornthepvarakui T, Gottschalk ME, Hayashi Y \& Refetoff S. Brief report: resistance to thyrotropin caused by mutations in the thyrotropin-receptor gene. New England Journal of Medicine 1995 332 155-160.

9 Sunthornthepvarakul T, Hayashi Y \& Refetoff S. Polymorphism of a variant human thyrotropin receptor (hTSHR) gene. Thyroid 1994 4 147-149.

10 Gustavsson B, Eklof C, Westermark K, Westermark B \& Heldin NE. Functional analysis of a variant of the thyrotropin receptor gene in a family with Graves' disease. Molecular and Cellular Endocrinology $1995111167-173$.

11 Gabriel EM, Bergert ER, Grant CS, Van Heerden JA, Thompson GB \& Morris JC. Germline polymorphism of codon 727 of human thyroid-stimulating hormone receptor is associated with toxic multinodular goiter. Journal of Clinical Endocrinology and Metabolism 199984 3328-3335.

12 Villanueva R, Inzerillo AM, Tomer Y, Barbesino G, Meltzer M, Concepcion ES, Greenberg DA, Maclaren N, Sun ZS, Zhang DM, Tucci S \& Davies TF. Limited genetic susceptibility to severe Graves' ophthalmopathy: no role for CTLA-4 but evidence for an environmental etiology. Thyroid 200010 791-798.

13 Sale MM, Akamizu T, Howard TD, Yokota T, Nakao K, Mori T, Iwasaki H, Rich SS, Jennings-Gee JE, Yamada M \& Bowden DW. Association of autoimmune thyroid disease with a microsatellite marker for the thyrotropin receptor gene and CTLA-4 in a Japanese population. Proceedings of the Association of American Physicians 1997109 453-461.

14 Hiratani H, Bowden DW, Ikegami S, Shirasawa S, Shimizu A, Iwatani Y \& Akamizu T. Multiple SNPs in intron 7 of thyrotropin receptor are associated with Graves' disease. Journal of Clinical Endocrinology and Metabolism 200590 2898-2903.

15 Akamizu T, Sale MM, Rich SS, Hiratani H, Noh JY, Kanamoto N, Saijo M, Miyamoto Y, Saito Y, Nakao K \& Bowden DW. Association of autoimmune thyroid disease with microsatellite markers for the thyrotropin receptor gene and CTLA-4 in Japanese patients. Thyroid $2000 \mathbf{1 0} 851-858$.

16 De Roux N, Misrahi M, Chatelain N, Gross B \& Milgrom E. Microsatellites and PCR primers for genetic studies and genomic sequencing of the human TSH receptor gene. Molecular and Cellular Endocrinology 1996117 253-256.

17 Peeters RP, Van Toor H, Klootwijk W, De Rijke YB, Kuiper GG, Uitterlinden AG \& Visser TJ. Polymorphisms in thyroid hormone pathway genes are associated with plasma TSH and iodothyronine levels in healthy subjects. Journal of Clinical Endocrinology and Metabolism $2003 \mathbf{8 8} 2880-2888$.

18 Hansen PS, Van Der Deure WM, Peeters RP, Iachine I, Fenger M, Sørensen TIA, Kyvik KO, Visser TJ \& Hegedüs L. The impact of a TSH receptor gene polymorphism (Asp727Glu) on thyroid function and size in a healthy Danish twin population. 31st Annual Meeting of the European Thyroid Association, Naples, Italy, 2006 (Abstract P 168). 
19 Van Der Deure WM, Uitterlinden AG, Pols HAP, Peeters RP \& Visser TJ. The TSH receptor Asp727Glu polymorphism is associated with higher bone mineral density and bone mineral content. 13th International Thyroid Congress, Buenos Aires, Argentina, 2005 (Abstract O 57).

20 Nogueira CR, Kopp P, Arseven OK, Santos CL, Jameson JL \& Medeiros-Neto G. Thyrotropin receptor mutations in hyperfunctioning thyroid adenomas from Brazil. Thyroid 19999 1063-1068.

21 Sykiotis GP, Neumann S, Georgopoulos NA, Sgourou A, Papachatzopoulou A, Markou KB, Kyriazopoulou V, Paschke R, Vagenakis AG \& Papavassiliou AG. Functional significance of the thyrotropin receptor germline polymorphism D727E. Biochemical and Biophysical Research Communications 2003301 1051-1056.

22 Dechairo BM, Zabaneh D, Collins J, Brand O, Dawson GJ, Green AP, Mackay I, Franklyn JA, Connell JM, Wass JA, Wiersinga WM, Hegedus L, Brix T, Robinson BG, Hunt PJ, Weetman AP, Carey AH \& Gough SC. Association of the TSHR gene with Graves' disease: the first disease specific locus. European Journal of Human Genetics $2005131223-1230$

23 Cuddihy RM, Bryant WP \& Bahn RS. Normal function in vivo of a homozygotic polymorphism in the human thyrotropin receptor. Thyroid $1995 \mathbf{5} 255-257$.

24 Loos U, Hagner S, Bohr UR, Bogatkewitsch GS, Jakobs KH \& Van Koppen CJ. Enhanced cAMP accumulation by the human thyrotropin receptor variant with the Pro52Thr substitution in the extracellular domain. European Journal of Biochemistry 1995 $23262-65$.

25 Tonacchera M \& Pinchera A. Thyrotropin receptor polymorphisms and thyroid diseases. Journal of Clinical Endocrinology and Metabolism 200085 2637-2639.

26 Calebiro D, De Filippis T, Lucchi S, Covino C, Panigone S, BeckPeccoz P, Dunlap D \& Persani L. Intracellular entrapment of wildtype TSH receptor by oligomerization with mutants linked to dominant TSH resistance. Human Molecular Genetics 200514 2991-3002.

27 Tomer Y, Barbesino G, Keddache M, Greenberg DA \& Davies TF Mapping of a major susceptibility locus for Graves' disease (GD-1) to chromosome 14q31. Journal of Clinical Endocrinology and Metabolism 199782 1645-1648.

28 Ban Y, Greenberg DA, Concepcion ES \& Tomer Y. A germline single nucleotide polymorphism at the intracellular domain of the human thyrotropin receptor does not have a major effect on the development of Graves' disease. Thyroid 200212 1079-1083.

29 Cuddihy RM, Dutton CM \& Bahn RS. A polymorphism in the extracellular domain of the thyrotropin receptor is highly associated with autoimmune thyroid disease in females. Thyroid $1995589-95$.

30 Ho SC, Goh SS \& Khoo DH. Association of Graves' disease with intragenic polymorphism of the thyrotropin receptor gene in a cohort of Singapore patients of multi-ethnic origins. Thyroid 2003 13 523-528.

31 Nakabayashi K, Matsumi H, Bhalla A, Bae J, Mosselman S, Hsu SY \& Hsueh AJ. Thyrostimulin, a heterodimer of two new human glycoprotein hormone subunits, activates the thyroid-stimulating hormone receptor. Journal of Clinical Investigation 2002109 1445-1452.

32 Muhlberg T, Herrmann K, Joba W, Kirchberger M, Heberling HJ \& Heufelder AE. Lack of association of nonautoimmune hyperfunctioning thyroid disorders and a germline polymorphism of codon 727 of the human thyrotropin receptor in a European Caucasian population. Journal of Clinical Endocrinology and Metabolism 2000 85 2640-2643.

33 Chistiakov DA, Savost'anov KV, Turakulov RI, Petunina N, Balabolkin MI \& Nosikov VV. Further studies of genetic susceptibility to Graves' disease in a Russian population. Medical Science Monitor 20028 CR180-CR184.

34 Chistiakov DA. Thyroid-stimulating hormone receptor and its role in Graves' disease. Molecular Genetics and Metabolism $2003 \mathbf{8 0}$ $377-388$.
35 Chistiakov DA, Savost'anov KV \& Turakulov RI. Screening of SNPs at 18 positional candidate genes, located within the GD-1 locus on chromosome 14q23-q32, for susceptibility to Graves' disease: a TDT study. Molecular Genetics and Metabolism 200483 264-270.

36 Ioannidis JP. Genetic associations: false or true? Trends in Molecular Medicine 20039 135-138.

37 Bell A, Gagnon A, Grunder L, Parikh SJ, Smith TJ \& Sorisky A. Functional TSH receptor in human abdominal preadipocytes and orbital fibroblasts. American Journal of Physiology. Cell Physiology 2000279 C335-C340.

38 Crisanti P, Omri B, Hughes E, Meduri G, Hery C, Clauser E, Jacquemin C \& Saunier B. The expression of thyrotropin receptor in the brain. Endocrinology 2001142 812-822.

39 Bahn RS, Dutton CM, Natt N, Joba W, Spitzweg C \& Heufelder AE. Thyrotropin receptor expression in Graves' orbital adipose/connective tissues: potential autoantigen in Graves' ophthalmopathy. Journal of Clinical Endocrinology and Metabolism 199883 998-1002.

40 Paschke R \& Geenen V. Messenger RNA expression for a TSH receptor variant in the thymus of a two-year-old child. Journal of Molecular Medicine 199573 577-580.

41 Abe E, Marians RC, Yu W, Wu XB, Ando T, Li Y, Iqbal J, Eldeiry L, Rajendren G, Blair HC, Davies TF \& Zaidi M. TSH is a negative regulator of skeletal remodeling. Cell 2003115 151-162.

42 Haraguchi K, Shimura H, Kawaguchi A, Ikeda M, Endo T \& Onaya T. Effects of thyrotropin on the proliferation and differentiation of cultured rat preadipocytes. Thyroid 19999 613-619.

43 Hernandez A, Fiering S, Martinez E, Galton VA \& Germain D, St. The gene locus encoding iodothyronine deiodinase type 3 (Dio3) is imprinted in the fetus and expresses antisense transcripts. Endocrinology 2002143 4483-4486.

44 Schneider MJ, Fiering SN, Pallud SE, Parlow AF, Germain DL, St \& Galton VA. Targeted disruption of the type 2 selenodeiodinase gene (DIO2) results in a phenotype of pituitary resistance to T4. Molecular Endocrinology 200115 2137-2148.

45 Berry MJ, Grieco D, Taylor BA, Maia AL, Kieffer JD, Beamer W, Glover E, Poland A \& Larsen PR. Physiological and genetic analyses of inbred mouse strains with a type I iodothyronine $5^{\prime}$ deiodinase deficiency. Journal of Clinical Investigation 199392 1517-1528.

46 Mentuccia D, Proietti-Pannunzi L, Tanner K, Bacci V, Pollin TI, Poehlman ET, Shuldiner AR \& Celi FS. Association between a novel variant of the human type 2 deiodinase gene Thr92Ala and insulin resistance: evidence of interaction with the Trp64Arg variant of the beta-3-adrenergic receptor. Diabetes $200251880-883$.

47 Peeters RP, Van Den Beld AW, Attalki H, Toor H, De Rijke YB, Kuiper GG, Lamberts SW, Janssen JA, Uitterlinden AG \& Visser TJ. A new polymorphism in the type II deiodinase gene is associated with circulating thyroid hormone parameters. American Journal of Physiology. Endocrinology and Metabolism 2005289 E75-E81.

48 Bianco AC, Salvatore D, Gereben B, Berry MJ \& Larsen PR. Biochemistry, cellular and molecular biology, and physiological roles of the iodothyronine selenodeiodinases. Endocrine Reviews 200223 38-89.

49 Leonard JL \& Koehrle J. Intracellular Pathways of Iodothyronine Metabolism Philadelphia, PA, USA: Lippincot Williams \& Wilkins, 2000.

50 Peeters RP, Wouters PJ, Kaptein E, Van Toor H, Visser TJ \& Van Den Berghe G. Reduced activation and increased inactivation of thyroid hormone in tissues of critically ill patients. Journal of Clinical Endocrinology and Metabolism 200388 3202-3211.

51 Peeters RP, Van Den Beld AW, Van Toor H, Uitterlinden AG, Janssen JAMJL, Lamberts SWF \& Visser TJ. A polymorphism in type I deiodinase (D1) is associated with circulating free IGF-I levels and body composition in humans. Journal of Clinical Endocrinology and Metabolism 200590 256-263.

52 Steinsapir J, Bianco AC, Buettner C, Harney J \& Larsen PR. Substrate-induced down-regulation of human type 2 deiodinase 
(hD2) is mediated through proteasomal degradation and requires interaction with the enzyme's active center. Endocrinology 2000 141 1127-1135.

53 Donda A \& Lemarchand-Beraud T. Aging alters the activity of 5'deiodinase in the adenohypophysis, thyroid gland, and liver of the male rat. Endocrinology 1989124 1305-1309.

54 Gereben B, Kollar A, Harney JW \& Larsen PR. The mRNA structure has potent regulatory effects on type 2 iodothyronine deiodinase expression. Molecular Endocrinology 200216 1667-1679.

55 Hussain MA, Schmitz O, Jorgensen JO, Christiansen JS, Weeke J, Schmid C \& Froesch ER. Insulin-like growth factor I alters peripheral thyroid hormone metabolism in humans: comparison with growth hormone. European Journal of Endocrinology 1996 134 563-567.

56 Angervo M, Leinonen P, Koistinen R, Julkunen M \& Seppala M. Tri-iodothyronine and cycloheximide enhance insulin-like growth factor-binding protein-1 gene expression in human hepatoma cells. Journal of Molecular Endocrinology 199310 7-13.

57 Maia AL, Kim BW, Huang SA, Harney JW \& Larsen PR. Type 2 iodothyronine deiodinase is the major source of plasma T3 in euthyroid humans. Journal of Clinical Investigation 2005115 2524-2533.

58 Canani LH, Capp C, Dora JM, Meyer EL, Wagner MS, Harney JW, Larsen PR, Gross JL, Bianco AC \& Maia AL. The type 2 deiodinase A/G (Thr92Ala) polymorphism is associated with decreased enzyme velocity and increased insulin resistance in patients with type 2 diabetes mellitus. Journal of Clinical Endocrinology and Metabolism $2005903472-3478$.

59 Peeters RP, Van Den Beld AW, Attalki H, Toor H, Kuiper GG, Lamberts SW, Janssen JA, Uitterlinden AG \& Visser TJ. Polymorphisms in the type 2 deiodinase (D2) are associated with serum thyroid parameters and insulin resistance. 76th annual meeting of the American Thyroid Association, Vancouver, Canada, 2004 (P162).

60 Casla A, Rovira A, Wells JA \& Dohm GL. Increased glucose transporter (GLUT4) protein expression in hyperthyroidism. Biochemical and Biophysical Research Communications 1990171 182-188.

61 Viguerie N, Millet L, Avizou S, Vidal H, Larrouy D \& Langin D. Regulation of human adipocyte gene expression by thyroid hormone. Journal of Clinical Endocrinology and Metabolism 2002 87 630-634.
62 Liu YY, Schultz JJ \& Brent GA. A thyroid hormone receptor alpha gene mutation $(\mathrm{P} 398 \mathrm{H})$ is associated with visceral adiposity and impaired catecholamine-stimulated lipolysis in mice. Journal of Biological Chemistry 2003278 38913-38920.

63 Watanabe M, Houten SM, Mataki C, Christoffolete MA, Kim BW, Sato H, Messaddeq N, Harney JW, Ezaki O, Kodama T, Schoonjans K, Bianco AC \& Auwerx J. Bile acids induce energy expenditure by promoting intracellular thyroid hormone activation. Nature $2006439484-489$.

64 Romijn JA \& Fliers E. Sympathetic and parasympathetic innervation of adipose tissue: metabolic implications. Current Opinion in Clinical Nutrition and Metabolic Care 20058 440-444.

65 Guo TW, Zhang FC, Yang MS, Gao XC, Bian L, Duan SW, Zheng ZJ, Gao JJ, Wang H, Li RL, Feng GY, Clair D, St \& He L. Positive association of the DIO2 (deiodinase type 2) gene with mental retardation in the iodine-deficient areas of China. Journal of Medical Genetics 200441 585-590.

66 Appelhof BC, Peeters RP, Wiersinga WM, Visser TJ, Wekking EM, Huyser J, Schene AH, Tijssen JGP, Hoogendijk WJG \& Fliers E. Polymorphisms in type 2 deiodinase are not associated with wellbeing, neurocognitive functioning and preference for combined T4/T3 therapy. Journal of Clinical Endocrinology and Metabolism $2005906296-6299$.

67 Kester MH, Martinez De Mena R, Obregon MJ, Marinkovic D, Howatson A, Visser TJ, Hume R \& Morreale De Escobar G. Iodothyronine levels in the human developing brain: major regulatory roles of iodothyronine deiodinases in different areas. Journal of Clinical Endocrinology and Metabolism 200489 3117-3128.

68 Berghout A, Wiersinga WM, Smits NJ \& Touber JL. Interrelationships between age, thyroid volume, thyroid nodularity, and thyroid function in patients with sporadic nontoxic goiter. American Journal of Medicine 199089 602-608.

69 Rieu M, Bekka S, Sambor B, Berrod JL \& Fombeur JP. Prevalence of subclinical hyperthyroidism and relationship between thyroid hormonal status and thyroid ultrasonographic parameters in patients with non-toxic nodular goitre. Clinical Endocrinology (Oxf) $19933967-71$.

Received 9 June 2006

Accepted 29 August 2006 